\title{
Creative Destruction Theory Space as the Ultimate End for post-COVID-19 Recovery in Sub-Saharan Africa
}

\author{
Emerson Abraham Jackson
}

\begin{abstract}
Research Scholar, Centre of West African Studies, University of Birmingham, Birmingham B15 2TT, UK; Research Economist, Bank of Sierra Leone

email: emersonjackson69@gmail.com; EAJ392@bham.ac.uk; ejackson@bsl.gov.sl
\end{abstract}

DOI: 10.51865/EITC.2021.02.02

\begin{abstract}
The emergence of COVID-19 has made it ever more onerous for the world economy to rethink the way things are done and to be done. The need and almost compulsory way of services being catered for will never have been made so practically obvious without the influence of a pandemic like COVID-19. The world at some point in time was almost brought to a standstill, with services pertaining to supply-chain deliverables, education / professional development and many more almost brought to a halt. This paper has the platform for critically assessing the pathway SSA economies (SSA) should follow, notably creativity in new technologies, while adopting a stance on ISI approach in order to reduce its reliance on the importation of essential commodities, which seem to have been a worrying concern throughout the crisis of COVID-19. Suggestions for SSA economies to embrace the notion of creative destruction is the focal point in this paper for the realization of growth and development, while at the same time harnessing the power of human integrity to champion competitive innovation.
\end{abstract}

Keywords: creative destruction; COVID-19; Sub-Saharan Africa; well-being.

JEL Classification: A12; B13; O31.

\section{Introduction}

The emergence of COVID-19 has made it ever more onerous for the global economy to rethink the way things are done and to be done. The need and almost compulsory way of service delivery will never have been made so practically obvious without the influence of a pandemic like COVID-19. The world at some point in time was almost brought to a standstill, with services pertaining to supply-chain deliverables, education / professional development and many more almost brought to a halt. This to a greater extent affected the continuity of services pertaining to education as the heightened state of the pandemic meant that decisions were made for all educational institutions to shut down in a bid to save lives. In the midst of such a grave problem, innovative mindsets were emerging all around, masterminded through varied forms of technologies to make it worthwhile for services such as school and higher education learning, corporate training and also supply-chain operations to continue serving the needs of people (Jackson, forthcoming; Alvi and Gupta, 2020; UNESCO, 2020). 
The highly concentrated effort on globalization has been at the fore of critical discourse(s) given the skewed effort of capitalists to amass their thinking in the direction of profits, by taking advantage of cheap labour in countries with highly skilled workforce, while ignoring the importance of diverting investments in human resource capacity domestically (Jackson, 2020a). This thereby left countries and more particularly rich industrialised nations in a state of struggle in meeting the basics of human wants / needs when it was declared by the World Health Organisation that COVID-19 is a global health issue (Palayew et al, 2020). Countries were forced to close essential services, thereby bringing to the fore, problems of meeting the demands of people for essential goods and services, which were almost brought to a standstill due to a collapse in supply-chain network. Almost every means of transportation service delivery systems were grounded as people and entrepreneurs were also made to protect lives of vulnerable citizens. More disadvantageously, underdeveloped economies in the SSA region were gravely affected given their high dependence and exposed vulnerability on the importation of essential items for domestic consumption. The continued state of fragility also became more apparent in areas connected with the delivery of health care services - majority of the SSA economies have deplorable health facilities, which thereby require them to remodel their approach towards building domestic capacity at a sustained level.

In view of the aforementioned background information, this paper is motivated on the backdrop of addressing pertinent concerns around SSA's lagged pace of development when compared to the rest of the world. SSA economies have complacently relaxed for too long in addressing policies that are relevant in moving the region towards self-reliance, given their abundance of natural wealth. In view of challenges experienced across the global economy, particularly slow growth faced on account of the emergence of COVID19 pandemic, developed economies are now faced with a situation of carving their focus in a nationalistic way to minimise vulnerabilities when it comes to addressing incidence of pandemics. Therefore, the theoretical discourse in this paper is set to address the following objectives:

o Elaborate on the basic tenet of Schumpeter's creative destruction theory as a step towards capacitating self-reliant pathway for economies in the SSA region.

o Explore critical discourses pertaining to SSA's current state of development, especially in areas pertaining to human capacity in heath and new technologies.

o Proffer recommendations and policy stance(s) that will enshrine the effort of self-reliance on economies in SSA to address present and future challenges that COVID-19 has placed on the world economy.

In view of the above introduction, the rest of the paper is detailed as follows: Section two provide details of Schumpeter's creative destruction concept, while section three addresses the state of SSA economies, particularly in areas pertaining to health capacity and human resource investment in emerging technologies. Section four provides critical assessment of creative destruction as the ultimate approach for SSA economies in challenging the continued risks of COVID-19 pandemic in the African continent as a whole. Finally, section five concludes by highlighting relevant pointers for policy prescription and proffered recommendations for building capacity in individual SSA economies.

\section{Basics of the Schumpeterian Concept}

The concept of creative destruction as alluded by Schumpeter is making headway as a lasting legacy in Development thinking (Jackson, 2020d). Such approach is noticeably pursued in all areas of professional endeavours, more so in carving human innovative mindset to become creative thinkers, while at the same time harnessing their entrepreneurial prowess to expand wealth creation (Jackson, 2020b; Cozzi et al. 2017). Schumpeter's contribution to creative destruction was carved with the intention of developing the human 'innovative and 
entrepreneurial intellectual capacity' in a bid to make it possible for old fashioned means of doing things to be buried in tandem with emerging creativity - this is to make sure that human ways of doing things in the emergent world of new technologies supersede that of preceding innovations, through the ingenuity of human creativity (Jackson, 2020b; Kopp 2019; Velde, 2001). In the true sense of things, it is quite obvious that entrepreneurship, particularly in areas pertaining to new technologies connected with industrial production, service delivery network and also education (specifically teaching / learning) needs to take a new turn, which invariably may skew people's thoughts in the new normal, typically associated with the vagaries of emerging technologies.

According to Langroodi (2017), the Schumpeterian system of economic thought was carved synergistically between economic, historical, political, social and all other elements of processes modelled on the doctrine of capitalism. These highlighted processes as noted by Croitoru (2012) and Jackson (2020a) can be addressed as separate entities given the approach of the capitalist system to utilise profit maximisation as the ultimate goal of business continuity. This brings to light the successes of Schumpeter's creative destruction economics in all corners of the world, particularly in relation with the deadly COVID-19 pandemic, which requires collaboration of both internal and external entities, with the focus on improving human ingenuity in a bid to reduce vulnerabilities experienced across the world economy. The theory of creative destruction as presented by Schumpeter is based on reality, more so in relation to evolving challenges we face when it comes to dealing with natural pandemics. In this regard, Schumpeter's developmental theory has been centralized around the core theme of entrepreneurship (Jackson, 2020b), where human creativity is considered the most important tool in addressing difficult puzzles associated with COVID-19 pandemic, also likened with scriptural passages in the bible (God's revelation - Psalm 42, Galatians 6: 10, Ephesians 2: 8-9, etc.) to test human resilience and strength to stand the test of time.

According to Langroodi (2017), Schumpeterian philosophy is enshrined in a series of tenets, and amongst these includes the notion of "Business Cycle and selective Mechanism". The Business Cycle model is perceived as the unavoidable joint product of economic development dynamics as explained by Croitoru (2012). This is making it possible for competition to be the ultimate goal of business or institutional growth, but not to the extent of imitating rivals' ideas in a bid to create unnecessary boom in business operations. The notion of selective mechanism could be likened with that of evolutionary economics (Witt, 2008) that asserts the role of ingenuity in the human power of becoming endogenously different, which thereby makes it possible to produce something that is capable of destructively competing with existing ideas or concepts. Hence, in the face of Schumpeter's philosophy, both the notion of growth and business cycle dynamics could be thought of as mutually influential in spearheading disruptive innovation (Legrand \& Hagemann, 2017; Langroodi, 2017). Critically, the outcome of Schumpeter's creative destruction theory could be perceived as a painstaking process, to the extent that institutions, that are not strong in their vision of entrepreneurial ingenuity can simply find themselves in a state of collapse or mildly journeying through a process of liquidation or merger acquisition, where the focus is to protect livelihoods.

\section{State of Sub-Saharan African Economies}

Many of the highly rated strong economies in Sub-Saharan Africa, notably South Africa, Nigeria, Kenya, etc., have all experienced difficulties throughout the lean period of COVID-19, which is expected to continue with the threat of variant(s) of the pandemic (2020c). As enshrined in the UN Sustainable Development Goals (SDG) agenda (notably Goals 1-5 and 8), collaborative effort should be stepped up by leaders in the Sub-Saharan Africa (SSA) region to champion institutional capacity through support from established institutions like the African Union (AU) and the African Development Bank (AfDB) to makes sure resources are targeted at 
things that bring respite to the continued risks that COVID-19 poses across the SSA region. In this regard, effort will need to be channelled in the direction of supporting capacity development through "Science Technology Engineering and Mathematics (STEM)" for all citizens, irrespective of race, gender and other human attributes (Jackson, 2020b; Jackson and Jackson, 2020).

The reality of COVID-19 is gravely impacting on macroeconomic stability for many of the SSA economies. This is manifesting itself through high inflation and plummeted growth rates. This in reality can be attributed to low productivity in the global economy, which for many of the highly commodity dependent economies like Nigeria, the impact is crystalizing itself through reduced revenue receipts from Crude Oil sales. Table 1 below provide an illustration of growth projection for SSA economies up to the end of 2021.

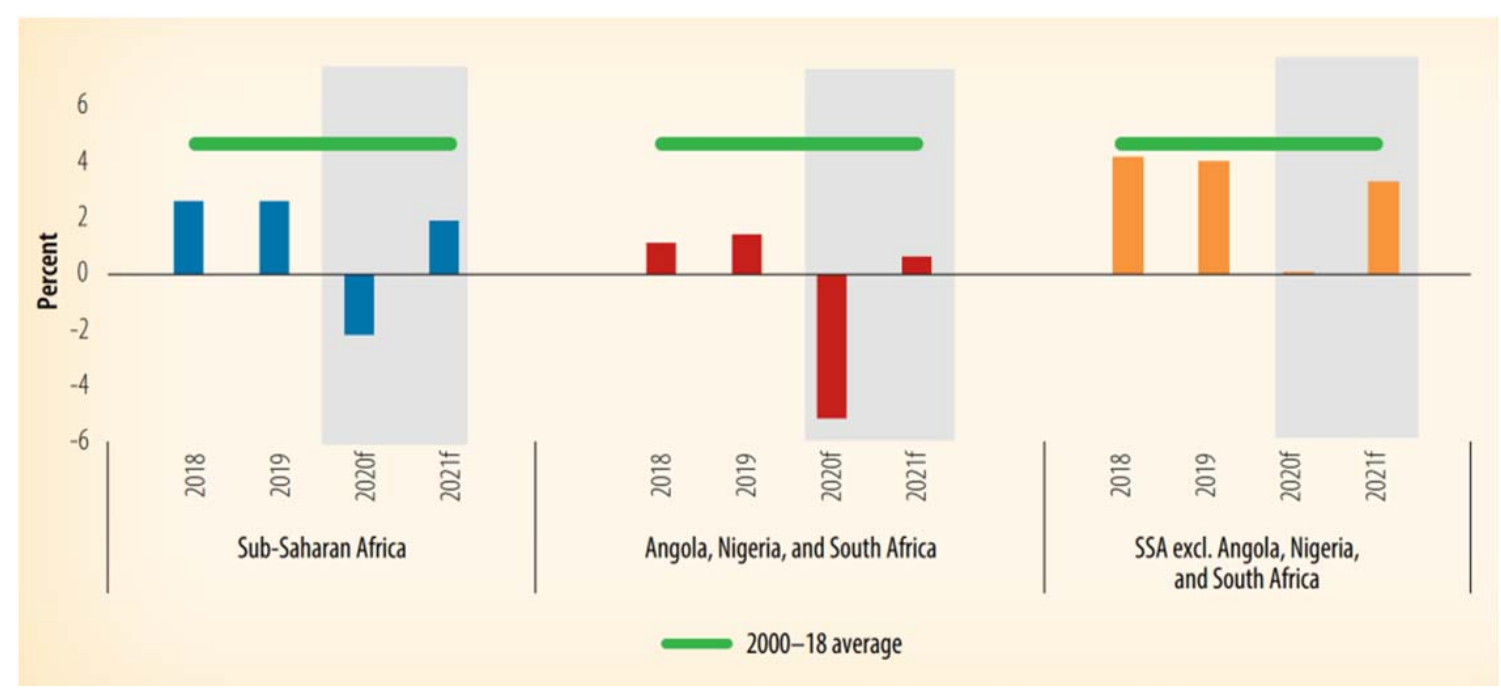

Fig. 1. Growth Projections for SSA in 2020 and 2021

Source: The Brookings Institute.

As shown in Figure 1 above, the heightened state of COVID-19 revealed itself harshly for all the highlighted economic groups, with negative growth rates dipping as low as $-6 \%$ for economies like Nigeria, Angola and South Africa that also joined the BRIC group of economies in 2010. Despite the hope of a revived growth prospect as shown for the entire SSA economies, threat of a second-wave of the COVID-19 pandemic is tainting the positive outlook with caution. Majority of the SSA economies are only just in the process of rolling-out the vaccine to vulnerable groups, with fears still looming about mutation of the virus. While COVID-19 is still posing threat to the recovery process in developed economies, there is bleak hope for many of the SSA economies given their high dependence on the importation of essential items for domestic consumption.

Despite low risk of COVID-19 experienced in the SSA region when compared to the situation in Latin America, Asia and developed economies, there is a high risk looming about its widespread in the continent due to poor health facilities prevalent in many of the economies. In a bid to save lives, SSA economies have also witnessed scale-down operations in production output. Equally, with curtailed operation in supply-chain network, many economies also experienced reduced income earned from exports (Kumar et al, 2020). Such situation also meant that the ultimate end is for governments to resort to high domestic borrowing as a way of meeting basic operations pertaining to salary payments and other high intensive capital budgetary expenditures like road construction, investments in basic health provision and many more. 


\section{Creative Destruction - the Ultimate End for Sub-Saharan African Economies}

In view of the aforementioned discourses pertaining to Schumpeter's creative destruction concept, one will be most inclined to support the call for a drastic approach to Sub-Saharan Africa's move in the direction of adopting creative destruction space in a bid to becoming selfreliant. The long standing informality in majority of the SSA economies needs to be remodeled in a concerted way that makes it possible to utilise human resources to break through the dark age of retrogression witnessed in the continent as a whole.

More specifically, individual economies will need to adopt robust policy measures that embrace investment in all sectors, but with specific attention paid to creativity in health technologies, while at the same time ensuring the dominant channel of informality, which has been the norm, is remodelled in the best interest of all. In this regard, government agencies connected with human well-being, education and many more should continue to work in the interest of supporting productive means through which governments can generate revenues to protect the vulnerable. In this regard, the informal economy must be encouraged to contribute meaningfully to revenue generation processes by ensuring people pay taxes to protect their state of vulnerability in times of shock(s) as in the case with COVID-19, while also utilising excesses to support governments' agenda of executing essential service provision to vulnerable groups.

Despite the bitter experiences of COVID-19 in the world economy, it is imperative for leaders in SSA economies to start thinking through the line of creativity for the good of nation building, while also targeting self-reliance as the way forward in addressing all of the SDG goals. While many economies in the Asian continent have strived to utilise resources to capacitate national approach to development, the influence of patronized politics in many of the SSA economies is still infiltrating into the fabrics of people's approach to developing an unpatriotic attitude in fostering policies capable of developing human entrepreneurial and competitive spirit (Jackson and Jabbie, 2020a; Jackson and Jabbie, 2019). The experience of COVID-19 is a bitter lesson, while a well thought through process that is supported by transparent governance structure in all SSA economies will be most welcomed as a way of reducing widespread vulnerabilities prevalent in people's lives.

With the level of disruption caused by COVID-19 pandemic in the global economy, virtual means of technologies seem to be the operational vogue of doing things, and this will continue in the foreseeable future. In this regard, SSA economies will need to seek ways of removing themselves out of the comfort of dependence and heavy reliance on imports from their counterparts in the developed economies. As shown in Figure 2, it is clear that for SSA economies to make a leap in the new normal of technologized way of doing things, effort should be skewed in the direction of increasing investment in varied forms of technologies, highly focused in the direction of medical technologies to fight the continued risks posed by the COVID-19 pandemic and other forms of imminent natural disasters, notably climate change (Arambala, 2020; Osseni, 2020). 

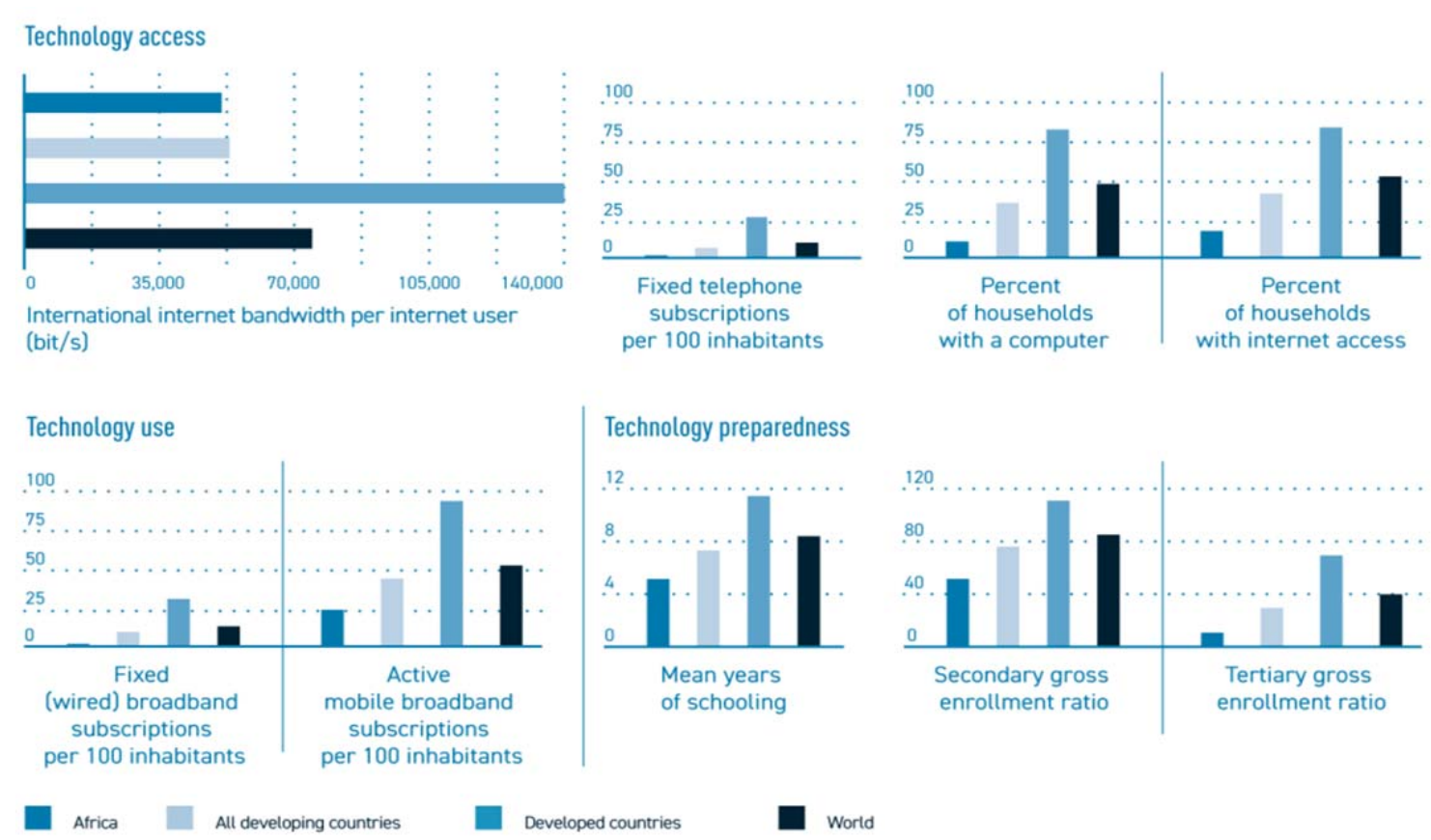

Fig. 2. State of SSA's Information and Communication Technology Development Indicators Source: The Brookings Institute.

Figure 2 above indicate that developing economies of which SSA is part of, need to get themselves in a prepared state to increase investment / spending to address increase demand for technology usage that COVID-19 has placed on the world economy (Jabbie, 2021). To some extent, the use of technology platforms like Whatsapp is resounding itself positively in the SSA region. There is a need to develop a well-planned approach in ensuring human integrity is utilised productively as a way of taking advantage of emerging technologies, given the imposition of (physical) restriction on human movements throughout the heightened period of COVID-19.

\section{Conclusion and Relevant Pointers for Policy Guidance}

The way forward to confronting the plethora of problems that COVID-19 has brought in the world economy and particularly Sub-Saharan Africa is to develop a critical mindset about how things are done, but with the focus of acknowledging that creative destruction as coined by Schumpeter is the ultimate approach. For a long time, SSA economies have developed complacent approach to the importation of essential items in addressing domestic consumption needs. This to a greater extent has exposed their vulnerabilities to what seem to be more prominent with the emergence of COVID-19 pandemic. Therefore, the way out of the unanswered problem is to be self-critical about the state of poorly managed systems in many of the SSA economies.

As emphasised by Jackson and Jabbie (2020), an inward approach to Import Substitution Industrialization (ISI) model and its calibration to address immediate concerns should be reengineered. Even though critics have expressed its failure in many of the African economies, successes about its management in the Asian tiger economies can confirm ISI as a sound model for strengthening capacity development in SSA general.

As opposed to earlier implementation of ISI model in SSA, which was highly influenced by patronization from political connectedness and rent seeking, the new focus must embrace a 
culture whereby people can only be rewarded for being productive (Jackson, 2019). In this regard, governments in SSA economies must endeavour to embrace collaboration through Public Private Partnership (PPP) arrangements, which will also inform would-be investors in other parts of the world, more so Diasporas about the need to become part of a global development chain. Effort must also be pursued in stressing the importance of investment in Science, Technology, Engineering and Mathematics (STEM), where both men and women are incorporated as equals in the process of championing growth at national level

On the subject of STEM, many countries like South Africa and Nigeria for example have made headway towards trending in the direction of the new development pathway, notably referred to as the 'Fourth Industrial Revolution (FIR)'. As the focus of this paper is tilted towards discourses around the subject of creative destruction, there is a need for governance structure in individual economies to direct their attention towards empowering human skills in areas pertaining to "Artificial Intelligence (AI), Cloud Computing and the Internet of Things (IoT)", which characterizes the notion of FIR. In order to make this a possible venture, governments in SSA economies must endeavour to invest heavily in developing human potential, while at the same time building the necessary infrastructural capacity that will allow human beings to fully utilise available facilities. With reference to Figure 2 above, there is clear indication indicating the existence of disparity between developed, all developing countries, Asia and Africa in general. This gap is an attestation to show that SSA economies have lagged behind their counterpart in the Asian bloc.

Given the mixed cultural attributes of the population structure in SSA, effort should be championed through use of expert knowledge from academics in higher education and Thinktank institutions to explore the depth of cultural diversity, more so in terms of religious fragmentation and people's lifestyle as a way of making it worthwhile for the process to be made an all-encompassing effort.

In conclusion on the topical discourse of creative destruction, there is a need for governments to focus attention on the delivery of essential services in meeting basic consumption needs for Africans, while at the same time engineering a system of supporting sustainable development activities that focuses attention in providing decent means of work and economic growth for individual economies (Jackson and Jabbie, 2020b; Jackson et al, 2020). Critical voices, championed through Schumpeter's creative destruction theory is an essential part of the development process in capacitating SSA economies, particularly with the continued threat of COVID-19 and other unknown pandemics threatening stability in the world economy.

\section{Disclaimer}

Views expressed in this article are those of the author and do not in any way reflect any of the aforementioned institutions.

\section{References}

1. Alvi, M., and Gupta, M. (2020). Learning in times of lockdown: how Covid-19 is affecting education and food security in India. Food Sec. 12, 793-796 (2020). https://doi.org/10.1007/s12571020-01065-4.

2. Arambala, G. (2020). Empowering the Poor and the Front-liners; Equality of Capability in the Time of COVID-19 Pandemic. Working Paper. Retrieved from: https://www.researchgate.net/publication/341283652 Empowering the Poor and the Frontliners Equality of Capability in the Time of COVID-19 Pandemic

3. Cozzi, G., Pataracchia, B., Pfeiffer, P., Ratto, M. (2017) How much Keynes and how much Schumpeter? An estimated macromodel of the U.S. economy, JRC working papers in Economics and fFinance, 2017/1. European Commission. 
4. Croitoru, A. (2012). Schumpeter, J.A., 1934 (2008), The Theory of Economic Development: An Inquiry into Profits, Capital, Credit, Interest and the Business Cycle, Journal of Comparative Research in Anthropology and Sociology, 2, 137-148.

5. Jabbie, M. (2021). Rethinking Technology Sharing for Sustainable Growth and Development in Developing Countries. In: Leal Filho W., Azul A.M., Brandli L., Lange Salvia A., Wall T. (eds) Industry, Innovation and Infrastructure. Encyclopedia of the UN Sustainable Development Goals. Springer. https://doi.org/10.1007/978-3-319-71059-4_57-1.

6. Jackson, E.A. (2019). Systemic Health Care Failure as a Symptom of Market Failure in Sierra Leone. South African Journal of Public Health. 3(4), 72-78. http://dx.doi.org/10.2139/ssrn.3439934.

7. Jackson, E.A. (forthcoming). Efficacy of virtual technology as the way forward for teaching and learning with the experience of a Global Pandemic.

8. Jackson, E.A. (2020a). Emerging innovative thoughts on globalization amidst the contagion of COVID-19. In: Leal Filho W., Azul A., Brandli L., Özuyar P., Ozuyar, P.G. (eds), Industry, Innovation and Infrastructure: Encyclopedia of Sustainable Development Goals, Springer. https://doi.org/10.1007/978-3-319-71059-4 131-1.

9. Jackson, E.A. (2020b). Economics of technology innovation for sustainable growth - Reference to Sub-Saharan Africa (SSA) region, In: Leal Filho W., Azul A., Brandli L., Ozuyar, P.G. (eds.) Industry, Innovation and Infrastructure. Encyclopedia of the UN Sustainable Development Goals. Springer. https://doi.org/10.1007/978-3-319-71059-4 128-1.

10. Jackson, E.A. (2020c). Innovative educational technologies for early-years curriculum delivery: A theoretical roadmap for economies in Sub-Saharan Africa (SSA). Economic Insights - Trends and Challenges, 9(2), 11-21.

11. Jackson, E.A. (2020d). Fostering sustainable innovation through creative destruction theory, In: Leal Filho W., Azul A., Brandli L., Özuyar P., Ozuyar, P.G. (ed.) Industry, Innovation and Infrastructure. Encyclopedia of the UN Sustainable Development Goals. Springer. https://doi.org/10.1007/978-3-319-71059-4_119-1.

12. Jackson, E.A., Jabbie, M. (2019). Understanding Market Failure in the Developing Country Context. In, Wa617lter L. Filho (eds), Decent Work and Economic Growth: Encyclopaedia of Sustainable Development Goals. Springer Nature. https://doi.org/10.1007/978-3-319-71058-7 44-1.

13. Jackson, E.A. and Jabbie, M. (2020a). Twin Deficits hypothesis as an indication of government failure in Sierra Leone: An empirical investigation (2007 to 2018). Journal of Economic Policy Researches, 7(1), 43-68. https://doi.org/10.26650/JEPR658440.

14. Jackson, E.A. and Jabbie, M (2020b). Import Substitution Industrialization (ISI): An approach to global economic sustainability. In: Leal Filho W., Azul A., Brandli L., Ozuyar, P.G. (ed.), Industry, Innovation and Infrastructure: Encyclopedia of Sustainable Development Goal, Springer Nature. https://doi.org/10.1007/978.3.319.71059-4 116.

15. Jackson, E.A. and Jackson. J. (2020). Global Perspectives on Gender Sensitivity and Economic Benefits. In Walters L, Filho et al (eds.). Gender Equality: Encyclopedia of Sustainable Development Goals, Springer Nature. https://doi.org/10.1007/978-3-319-70060-1_61-1.

16. Jackson, E.A., Jackson, E., and Jackson, H. (2020). Nurturing Career Development for Human Resource Sustainable Development. In Walter L. Filho et al (eds.). Decent Work and Economic Growth: Encyclopedia of Sustainable Development Goal. Springer Nature.

17. Langroodi, F.E.(2017). Schumpeter's Theory of Economic Development: a Study of the Creative Destruction and Entrepreneurship Effects on the Economic Growth. Working Paper. GoetheUniversität Frankfurt am Main. https://www.researchgate.net/publication/324918904.

18. Kopp, C.M. (2019) Creative destruction. Available at: https://www.investopedia.com/terms/c/creativedestruction.asp. (Accessed: 18th March, 2021).

19. Kumar, A., Luthra, S., Mangla, K.S., and Kazançoğlu, Y. (2020). COVID-19 impact on sustainable production and operations management. Sustainable Operations and Computers, 1, 1-7. https://doi.org/10.1016/j.susoc.2020.06.001.

20. Osseni, I.A. (2020). COVID-19 pandemic in sub-Saharan Africa: preparedness, response, and hidden potentials. Trop Med Health, 48. https://doi.org/10.1186/s41182-020-00240-9.

21. Palayew, A., Norgaard, O., Safreed-Harmon, K., et al. (2020). Pandemic publishing poses a new COVID-19 challenge. Nat Him Behav. 4, 666-669. https://doi.org/10.1038/s41562-020-0911-0.

22. The Brookings Institute (2020). Growth Projections for SSA in 2020 and 2021. Retrieved from: https://www.brookings.edu/blog/africa-in-focus/2020/12/30/africa-growth-initiatives-top-5-figuresof-2020/. 
23. UNESCO. (2020). School closures caused by Coronavirus (Covid-19). Retrieved May 8, 2020. https://en.unesco.org/covid19/education response.

24. Velde, R. (2001). Schumpeter's Theory of Economic Development Revised, Eindhoven Centre for Innovation Studies.

25. Witt, U. (2008). What is specific about evolutionary economics? J Evol Econ, 18, 547-575. https://doi.org/10.1007/s00191-008-0107-7. 